\title{
Addition of Spirulina as Feed Supplement in the Ration on Production and Eggs Quality of the Sentul Chickens
}

\author{
Tuti Widjastuti" ${ }^{\#}$ E. Sujana ${ }^{\#}$, R. L.Balia ${ }^{\#}$ \\ ${ }^{\#}$ Faculty of Animal Husbandry, Padjadjaran University, Jalan Raya Bandung-Sumedang Km 21, 45363, Indonesia \\ Email: tuti_widjastuti@yahoo.com
}

\begin{abstract}
Sentul chicken is a specific chicken from Ciamis region, West Java, Indonesia, and it is a dual purpose type. To improve performance can be added with spirulina meal as a feed supplement. Spirulina is classified as blue-green algae or blue-green bacteria and can be as the source of protein. Spirulina is a source of carotenoids with the high content of beta-carotene and xanthophylls, so it can be used in rations to increase egg production. The purpose of this study was to obtain an effective level of use $n$ of spirulina in the Sentul chicken ration of the layer phase. The study used 50 female chickens aged seven months, which was kept in cages until two months and each cage contains two chickens. The method used was a completely randomized design with 5 treatments namely R0 (ration without spirulina), R1 (ration with 1\% spirulina addition), R 2 (addition of $1.5 \%$ ), R3 (addition of $2 \%$ ) and R4 (addition of 2 , $5 \%$ ) with five replications. Furthermore, treatment differences were tested using Duncan Multiple Range test. The measured variables were feed consumption, egg weight, hen day production, and feed conversion, thick of shell and egg yolk color. The results showed the addition of spirulina of $1.5-2 \%$ in the ration increased hen day production and egg quality but with the addition of $2.5 \%$, feed consumption, hen day production, and feed conversion decreased. It can be concluded that spirulina can be used as a feed supplement until $2 \%$ to give the best on production and eggs quality of Sentul chicken.
\end{abstract}

Keywords—spirulina; hen day production; feed conversion; egg quality; sentul chicken.

\section{INTRODUCTION}

Sentul local chicken is a specific one which comes from Ciamis region in West Java with grey feathers as its distinctive feature, with a variation of grey and brown yellows feathers and orderly arranged feathers in its breast like dragon scales [1]. Ciamis people also call Sentul chicken as 'Kulawu Chickens,' kulawu means grey since the plumage colors of Sentul chickens are dominated by grey [2]. Sentul chicken is a dual purpose type, can utilize for eggs and meat production. They can adapt to the environment, and it remains productive even though their diets are low of quality. They produce 120-140 eggs per year [3]. The weight of adult male chickens can reach 1300-3500 $\mathrm{g}$, whereas the weight of female adults is 800-2200 $\mathrm{g}$ [4]. Nowadays, Sentul chickens are raised for meat and egg industry. They are sold when their weights are about $750 \mathrm{~g}$ and the age of 2.5 [5]. However, like other local chickens such as Pelung and Kedu chickens, the population of Sentul chickens is declined and the status is in danger [5]. The egg of Sentul chicken has a high nutritional value which can be accepted by all consumers.

The yellow color of eggs has its charm, from observations of semi-intensive or intensive Sentul chicken maintenance, the color yellow of the egg is paler than the traditionally maintained eggs, so it is often rejected by the cake-making industry.

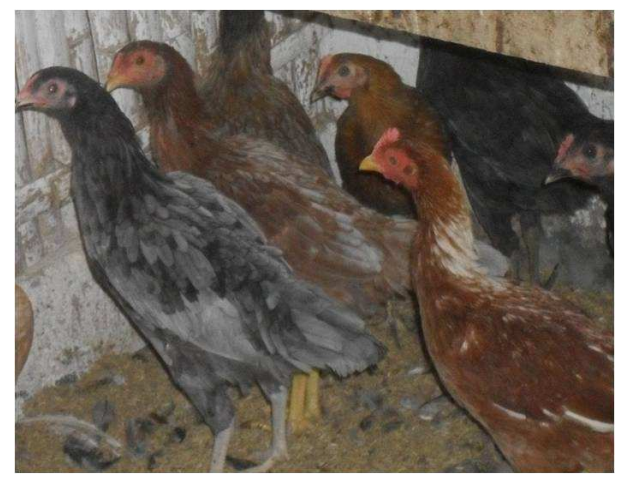

Fig. 1 The Sentul Hen

While this is developing the assumption that the color of egg yolks is often indicated the higher the nutritional content. The optimal performance of native chicken can only be realized if given rations of quality that meets the requirements in sufficient quantities and balanced. Fulfillment of nutrients in the diet can be done by adding the feed additives or feed supplement. It needs to be considered, as feed supplement can improve the quality and value of 
benefits in native chicken rations. Thus, it is necessary to find alternative feed additives are inexpensive, easy to obtain; the quality is good, as well as non-food [6]. The addition of supplement in the ration can overcome the problem of amino acid deficiency, vitamins, and minerals and can prevent protein deficiency. Spirulina (blue-green alga) is one of the high-quality natural feed supplement that can be used in animal and poultry nutrition [7]. There are two different species of Spirulina: Spirulina maxima and Spirulina platensis, with varying distribution throughout the world [8].

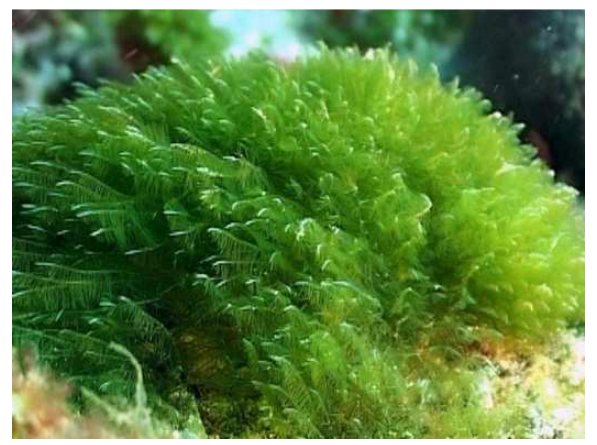

Fig. 2 Spirulina

Spirulina is wide can developed because rapid culture can produce spirulina ready for harvest for approximately 14 to 21 days. The growth of Spirulina sp culture on the laboratory scale lasts for 15 days while on the semi-mass scale is $15-30$ days. The initial cell density of Spirulina sp on the laboratory scale is 15.229 units $/ \mathrm{ml}$ and on the semi-mass scale is 28,417 units/ml. The peak cell population density Spirulina sp on the laboratory scale occurred on the 8th day of 181,963 units $/ \mathrm{ml}$, while for the semi-mass scale continues to increase the number of cell density on the 15th day of 295,317 units/ml [9]. Spirulina is a natural supplementary food which contains essential amino acids as well as macro and micro which enhance the metabolic process and stimulate egg production. Dried spirulina is a good nutritional source with a high protein content (260 - 770 $\mathrm{g} / \mathrm{kg})$ and a significant lipid content $(10-140 \mathrm{~g} / \mathrm{kg})$ [10][13]. Spirulina is high in unsaturated and polyunsaturated fatty acids in particular (25\% - 60\% of the total fatty acids), such as oleic acid, linoleic acid, gamma-linolenic acid and docosahexaenoic (DHA) [11]. It has also been reported that the amino acid pattern of these microalgae could be comparable with or superior to that of other vegetable foods and feeds and that they have a high nutrient digestibility. Spirulina digestibility is quite high at $82 \%$ for fresh spirulina and $65-75 \%$ for dried spirulina [12], [14]. In addition, spirulina contains substances such as pigments carotenoids such as $\beta$-carotene and zeaxanthin [15].

Besides, it contains vitamin B12, chlorophyll, carotenoids, minerals, gammaolenic acid (GLA) and some pigments, namely phycobilins, C-phycocyanin (C-PC) and allophycocyanin [14]. Spirulina contains essential amino acids, including leucine $540 \mathrm{mg} / 10 \mathrm{~g}$, lysine $290 \mathrm{mg} / 10 \mathrm{~g}$, methionine $140 \mathrm{mg} / 10 \mathrm{~g}$, threonine $320 \mathrm{mg} / 10 \mathrm{~g}$, tryptophane $90 \mathrm{mg} / 10 \mathrm{~g}$ and valine $400 \mathrm{mg} / 10 \mathrm{~g} \mathrm{[16]} \mathrm{and}$ contains carbohydrate $13.6 \%$ including glucose, rhamnose, mannose, xylose, and galactose. Spirulina also contains a lot of pigments and antioxidants, is a source of carotenoids with mixoxanthopyl and beta-carotene content reaching 0.2 to $0.4 \%$ of dry weight, so it can be used to improve egg quality [15]. Previous research states that adding $0.5-1.5 \%$ spirulina can improve egg quality and until $2 \%$ level results in the highest egg [13] because at that level there is the highest protein content compared to other treatments. The purpose of this study was to test the response of the addition of spirulina as a feed supplement in rations on the production and eggs quality of Sentul chicken from 1 to $2.5 \%$ on feed consumption, egg weight, hen day production, and feed conversion, thick of shell and egg yolk color.

\section{MATERIAL AND METHOD}

The study used 50 female chickens aged 7 months, which was kept in cages until 2 months and each cage contains 2 chickens. The ration was made by yellow corn meal, rice bran meal, soybean meal, fish meal, grit, $\mathrm{CaCo} 3$ and premix as additive feed in 16 percent protein and $2500 \mathrm{Kcal} / \mathrm{kg}$ of metabolizable energy. Spirulina used in this experiment are dried and then made into a meal. Chemical composition of Spirulina platensis [13] is summarized in Table1

TABLE I

CHEMICAL COMPOSITION OF SPIRULINA PLATENSIS

\begin{tabular}{|l|l|l|l|}
\hline $\begin{array}{l}\text { General } \\
\text { Composition }\end{array}$ & $(\%)$ & Phytopigments & Mg100 gr \\
\hline Protein & $55-69$ & Total carotenoids & $400-500$ \\
\hline Carbohydrates & $15-25$ & Carotenes & $160-260$ \\
\hline Fats (Lipids) & $5-6$ & Xanthophyll & $170-240$ \\
\hline Minerals (Ash) & $6-9$ & Chlorophyll & $1300-1700$ \\
\hline Moisture & $2.5-4.5$ & Phycocyanin & $15000-19000$ \\
\hline
\end{tabular}

The composition, nutrient and metabolizable energy contents are showed in Table 2 and Table 3 . The experiment rations were:

R0 Basal Ration without Spirulina

R1 Basal ration + Spirulina 1\%

R2 Basal ration + Spirulina $1.5 \%$

R3 Basal ration + Spirulina 2\%

R4 Basal ration + Spirulina $2.5 \%$

Completely Randomized Design (CRD) was used with 5 treatments, and each treatment was replicated 4 times. Furthermore, treatment differences were tested using Duncan Multiple Range test. For the analysis of egg yolk color was carried out using a nonparametric test namely Kruskal-Wallis test, if there were differences between treatments then continued with the Mann-Whitney test. The measured variables were feed consumption, egg weight, hen day production, and feed conversion, thick of shell and egg yolk color.

TABLE II

THE COMPOSITION OF BASAL RATION (\%)

\begin{tabular}{|l|l|l|l|l|l|}
\hline Ingredients & & & & & \\
\hline & $\mathrm{R} 0$ & $\mathrm{R} 1$ & $\mathrm{R} 2$ & $\mathrm{R} 3$ & $\mathrm{R} 4$ \\
\hline Yellow corn meal & 50.0 & 50.0 & 50.0 & 51.0 & 51.0 \\
\hline Soy-bean meal & 15.0 & 14.0 & 13.5 & 13.0 & 13.0 \\
\hline Rice bran meal & 25.0 & 25.0 & 25.0 & 23.0 & 22.5 \\
\hline Fish meal & 3.0 & 3.0 & 3.0 & 3.0 & 3.0 \\
\hline Spirulina meal & 0.0 & 1.0 & 1.5 & 2.0 & 2.5 \\
\hline Premix & 1.0 & 1.0 & 1.0 & 1.0 & 1.0 \\
\hline Grit & 3.0 & 3.0 & 3.0 & 4.0 & 4.0 \\
\hline
\end{tabular}




\begin{tabular}{|c|c|c|c|c|c|}
\hline Ca CO3 & 3.0 & 3.0 & 3.0 & 3.0 & 3.0 \\
\hline Total & 100.0 & 100.0 & 100.0 & 100.0 & 100.0 \\
\hline
\end{tabular}

TABLE III

THE NUTRIENT AND METABOLISM ENERGy CONTENT IN THE RATIONS

\begin{tabular}{|l|c|c|c|c|c|}
\hline Nutrients & $\mathrm{R} 0$ & $\mathrm{R} 1$ & $\mathrm{R} 2$ & $\mathrm{R} 3$ & $\mathrm{R} 4$ \\
\hline $\begin{array}{l}\text { Crude Protein } \\
(\%)\end{array}$ & 16.05 & 16.15 & 16.22 & 16.28 & 16.38 \\
\hline Crude Fat (\%) & 5.56 & 6.31 & 6.46 & 6.56 & 6.64 \\
\hline $\begin{array}{l}\text { Crude Fiber } \\
(\%)\end{array}$ & 4.86 & 4.80 & 4.87 & 4.68 & 4.65 \\
\hline Calcium (\%) & 3.65 & 3.85 & 3.89 & 4.26 & 4.30 \\
\hline $\begin{array}{l}\text { Phosphorus } \\
(\%)\end{array}$ & 0.65 & 0.67 & 0.69 & 0.71 & 0.71 \\
\hline Lysine (\%) & 0.87 & 0.89 & 0.86 & 0.87 & 0.87 \\
\hline $\begin{array}{l}\text { Methionine } \\
(\%)\end{array}$ & 0.67 & 0.69 & 0.65 & 0.66 & 0.66 \\
\hline $\begin{array}{l}\text { Metabolizable } \\
\text { energy } \\
\text { (Kcal/Kg) }\end{array}$ & 2510.50 & 2535.20 & 2540.58 & 2544.56 & 2545.45 \\
\hline \begin{tabular}{l} 
Sorce Prom \\
\hline
\end{tabular} & & & & \\
\hline
\end{tabular}

Source: Proximate analysis Laboratorium Ternak Ruminasia and Kimia Makanan Ternak, Animal Husbandry Universitas Padjadjaran, (2016)

\section{III. RESULTS AND DISCUSSION}

\section{A. Effect of Treatment on the Performance Production of Native Chicken}

The effect of spirulina level in the ration on feed consumption, hen day production and feed conversion of Sentul chicken, is shown in Table 4.

TABLE IV

EFFECT OF SPIRULINA LEVEL IN THE RATION ON FEED CONSUMPTION, HENDAY PRODUCTION AND FEED CONVERSION OF NATIVE CHICKEN.

\begin{tabular}{|c|c|c|c|}
\hline Treatment & $\begin{array}{c}\text { Feed } \\
\text { Consumption }(\mathrm{g})\end{array}$ & $\begin{array}{c}\text { Hen-day } \\
\text { Production } \\
(\%)\end{array}$ & $\begin{array}{l}\text { Feed } \\
\text { Conversion }\end{array}$ \\
\hline R0 & $89.80^{\mathrm{a}}$ & $46.74^{\mathrm{a}}$ & $4.02^{\mathrm{a}}$ \\
\hline R1 & $89.77^{\mathrm{a}}$ & $47.66^{\mathrm{a}}$ & $3.86^{\mathrm{a}}$ \\
\hline R2 & $89.08^{\mathrm{a}}$ & $49.34^{\mathrm{b}}$ & $3.32^{\mathrm{b}}$ \\
\hline R3 & $88.80^{\mathrm{b}}$ & $49.78^{\mathrm{b}}$ & $3.26^{\mathrm{b}}$ \\
\hline R4 & $86.65^{\mathrm{b}}$ & $47.07^{\mathrm{a}}$ & $3.77^{\mathrm{a}}$ \\
\hline
\end{tabular}

Description: The same Letter in the direction of the column shows no significant difference $(\mathrm{P}>0.05)$.

Notes:

$\mathrm{R} 0=$ Control ration (ration without spirulina )

$\mathrm{R} 1=$ Control ration + spirulina $1 \%$

$\mathrm{R} 2=$ Control ration + spirulina $1.5 \%$

$\mathrm{R} 3=$ Control ration + spirulina $2 \%$

$\mathrm{R} 4=$ Control ration + spirulina $2.5 \%$

1) Feed Consumption: In Table 4. Shows that feed consumption reduced with increased the level of spirulina in the rations. The analysis of variance showed that adding spirulina has a significant effect $(\mathrm{P}<0.05)$ on feed consumption. The use of spirulina in R3 and R4 treatments, feed consumption, was significantly lower than the R0, R1 and $\mathrm{R} 2$ treatments, although the ration was made with the same protein and energy levels. Its mean that the use spirulina from $1 \%$ until $1.5 \%$ in the rations did not influence palatability and chicken appetite. Feed consumption is strongly influenced by the palatability of feed ingredients of rationing. A decrease in feed consumption of R3 and R4 (2 $2.5 \%$ ) was caused to the aroma or excess fishy odor, thus reducing palatability. [13] Observed the decrease in feed intake and significant effect on the overall egg production with higher levels of algae. According to [17] that palatability is an important factor that determines the level of feed consumption, and palatability depends on the smell, taste, color, and texture of feed ingredients of rationing.

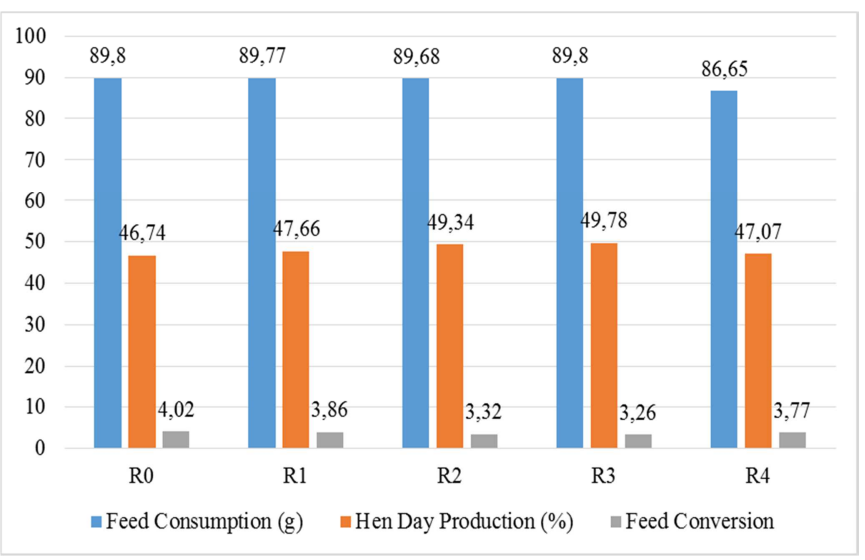

Fig. 3 Effect of spirulina level in the ration on feed consumption, hen-day production and feed conversion of Sentul chicken.

2) Hen-day production: Hen-day production percentage levels were variation, where R0 ration without spirulina is the lowest $(46.74 \%)$, and those adding $2 \%$ spirulina in the rations was the highest $(49.78 \%)$. Analysis of variance showed (Table 4) that by adding spirulina from $1.5 \%-2 \%$ (R2 and R3) in the ration was no significant different ( $\mathrm{P}>0.05)$, and significant difference to R0, R1 (1\%) and R4 (2.5\%) on hen-production. Hen-day production at R2 and R3 treatments was significantly higher than R1, R4, and R0 treatments. This is related to the use of spirulina of 1.5 -2\% (R2 and R3) can contributing higher amino acid lysine and methionine so can be absorbed optimally and will produce higher egg production (hen-day). The content of Lysine and methionine in Spirulina greatly affect egg production. In the treatment of R4, R1 and R0 were not significant, because in treatments R1 with spirulina dose $1 \%$ could not contribute enough lysine and methionine to increase egg production (hen-day), so that egg production tended to be no different with ration without spirulina (R0). In treatment R4 (2.5\%) the consumption of rations decreases because excess fishy odor so cannot contribute enough lysine and methionine so increase egg production (hen-day). Several authors reported that laying hens fed Spirulina-containing diets attained the best means of egg production and feed conversion compared with those of the control group [7][13]. Feeding Spirulinacontaining diets gave a beneficial effect on the productive performance of laying hens.

3) Feed conversion: From Table 4, it can be seen that the average feed conversion value in the various levels of spirulina was tendency going to decreased. Analysis of variance showed (Table 3) that by adding spirulina until 1.5 $-2 \%$ in the ration was not significantly influenced $(\mathrm{P}>0.05)$ on feed conversion, but has a significant effect $(\mathrm{P}<0.05)$ when using $2.5 \%$ spirulina in the ration. Values of feed conversion on treatment R2 (3.32) and R3 (3.26) are significantly lower than R 1 (3.86), R4 (3.77) and R0 (4.02). This is caused by the amount of production (output) on 
treatment R2, and R3 is higher than the amount of feed consumption (input), on the contrary in the treatment R4, R1 and $\mathrm{R} 0$ the amount of production (output) is lower with the amount of consumption (input), so it treatment R2 and R3 is more efficient According to opinions [Checke] the value of feed conversion can also be used to measure livestock productivity. In line with the present results, several authors reported that laying hens fed Spirulina-containing diets, especially those fed. $2 \%$ Spirulina containing diet attained the best means of egg production and feed conversion compared with those of the control group [18], [7], [13].

\section{B. Effect of Treatment on The Egg Quality of Native Chicken}

The effect of spirulina level in the ration on Egg Quality of native chicken is shown in Table 5 .

TABLE V

EFFECT OF SPIRULINA LEVEL IN THE RATION ON EGG QUALITY NATIVE CHICKEN

\begin{tabular}{|c|c|c|c|}
\hline Treatment & $\begin{array}{c}\text { Egg } \\
\text { Weight } \\
(\mathrm{g})\end{array}$ & $\begin{array}{c}\text { Thick of Shell } \\
(\mathrm{mm})\end{array}$ & $\begin{array}{c}\text { Egg yolk } \\
\text { color }\end{array}$ \\
\hline R0 & $40.08^{\mathrm{a}}$ & $0.24^{\mathrm{a}}$ & $9^{\mathrm{a}}$ \\
\hline R1 & $40.40^{\mathrm{a}}$ & $0.25^{\mathrm{a}}$ & $9^{\mathrm{a}}$ \\
\hline R2 & $41.90^{\mathrm{b}}$ & $0.25^{\mathrm{a}}$ & $11^{\mathrm{b}}$ \\
\hline R3 & $42.22^{\mathrm{b}}$ & $0.25^{\mathrm{a}}$ & $11^{\mathrm{b}}$ \\
\hline R4 & $40.22^{\mathrm{a}}$ & $0.24^{\mathrm{a}}$ & $12^{\mathrm{b}}$ \\
\hline
\end{tabular}

Description: The same Letter in the direction of the column shows no significant difference $(\mathrm{P}>0.05)$

\section{Notes:}

$\mathrm{R} 0=$ Control ration $($ ration without spirulina

$\mathrm{R} 1=$ Control ration + spirulina $1 \%$

$\mathrm{R} 2=$ Control ration + spirulina $1.5 \%$

$\mathrm{R} 3=$ Control ration + spirulina $2 \%$

$\mathrm{R} 4=$ Control ration +spirulina $2.5 \%$

1) Egg weight: The average eggs weight of native chicken obtained during the study ranged from 41.08 to 42.42 grams. Based on analysis of variance showed that the addition of spirulina in the ration gave a significant effect $(\mathrm{P}<.05)$ on the egg weight of Sentul chicken. By the addition of spirulina from 1.5 - 2\% (R2 and R3) in the ration, egg weight was higher than treatment $\mathrm{R} 0, \mathrm{R} 1$, and $\mathrm{R} 4$. This means the addition of spirulina until $2 \%$ in the ration gives a positive response to the egg weight This is because spirulina is a source protein between $55-65 \%$, besides it contains vitamin B12, chlorophyll, carotenoids, minerals, gammaolenic acid (GLA) and some pigments, namely phycobilins, C-phycocyanin (C-PC) and allophycocyanin [11]-[13]. Spirulina contains essential amino acids, including leucine $(10.9 \%)$, valine $(7.5 \%)$ and isoleucine $(6.8 \%)$, and contains carbohydrate $13.6 \%$ including glucose, rhamnose, mannose, xylose, and galactose [19]. This protein and amino acid content have a positive effect on the egg weight of Sentul chicken. This is in line with the opinion of [20] that the weight of eggs is influenced by proteins, fats and essential amino acids contained in the ration. Another factor that causes increased egg weight is the presence of antioxidants contained in spirulina. Antioxidants can be free in the body so that antioxidants can suppress the appearance of free radicals. This is supported by the opinion of [21] which states that antioxidants have an important role in preventing damage caused by free radicals that cause chickens to be healthy and can optimize the absorption of nutrients that have an increase in egg weight.

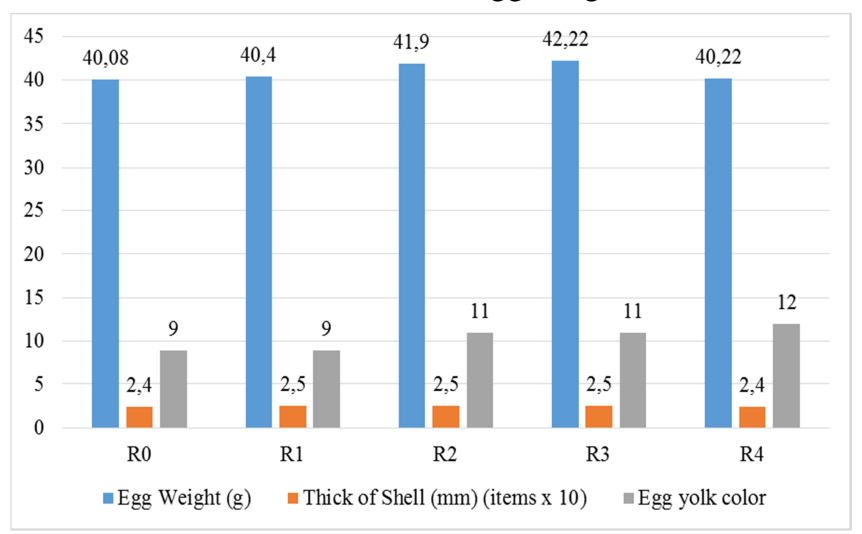

Fig. 4 Effect of spirulina level in the ration on Egg Quality Sentul Chicken

2) Thick of shell: From Table 4 the average of thickness shells obtained during the study ranged from 0.24 to 0.26 $\mathrm{mm}$. Based on the analysis of variance, the treatment of spirulina as feed additives in the ration gave no significant $(P>0.05)$ effect on the thickness of the chicken egg shells. This gives an illustration that the thickness of the shell of each treatment is in the same range, although there is an increase in thickness but not significantly different. This is due to the low mineral content contained in spirulina, namely the content of $\mathrm{Ca}$ as much as $0.70 \%$ and phosphorus $0.80 \%$, while calcium and phosphorous minerals much influence the thickness of the shell. In line with the opinion of [19] which states that the main nutrients that affect the thickness of shells are calcium, phosphorus and vitamin D3. Another factor affecting the thickness of the shell is feed consumption, where about $35-75 \%$ of calcium for eggshell formation comes from the feed consumed [24]. The level of feed consumption for treatment R0, R1, R2 was significantly higher than that of R3 and R4, but the eggshell thickness was the same as the treatment of R3 and R4. In R3 and R4 treatments, spirulina added more so that it added more minerals to the ration, although consumption was lower than $\mathrm{R} 0, \mathrm{R} 1$, and R3, in treatment R3 and R4 still produced the same eggshell thickness. [7], who reported that there were no significant differences in eggshell percentage, yolk index, albumen percentage, and Haugh unit as a result of feeding experimental diets containing Spirulina.

3) Egg yolk color: The results of observing the addition of spirulina to the egg yolk color of native chicken can be seen in Table 4. The mode of egg yolk color score in each treatment is in the range $9-12$. Egg yolks have more influence on consumer tastes and generally prefer eggs with a reddish yellow color that is a score between 11 and 13 . Egg yolk color has also been found to intensify linearly with increased dietary. Spirulina is an excellent source of nutrition and provides a superior natural source of carotenoids that are extremely effective in coloring egg yolks [13].

Based on the results of the Kruskal-Wallis test showed that the addition of spirulina in the ration increased the egg yolk color of Sentul chicken $(\mathrm{P}<0.05)$. The results of the 
Mann-Whitney test showed that the egg yolk color score of Sentul chicken those was not a significant difference among the treatment $\mathrm{R} 0$ and $\mathrm{R} 1$ and significant difference to the treatment R2, R3, and R4. The treatment of R2, R3 and R4 produced a significantly higher yolk score $(\mathrm{P}<0.05)$ compared to treatment $\mathrm{R} 0$ and $\mathrm{R} 1$. This means that the addition of spirulina from $1.5-2.5 \%$ level in the ration gives a positive response to the color of the yolk. This is caused by spirulina is a source of carotenoids with a high content of beta-carotene and xanthophyll which is a giver of color to the yolk to be more optimal. The color of the yolk arises due to the presence of carotenoids in eggs caused by ration containing carotene and xanthophyll pigments. According [13] the optimal level of yolk color (between 11.4 and 11.6 on the BASF yolk color fan) was achieved with $2.0-2.5 \%$ Spirulina in diet after only 7 days, the color levels of the egg yolks remained stable as long as the supplementation continued.

\section{CONCLUSION}

It can be concluded showed the addition of spirulina of $1.5-2 \%$ in the ration increased hen day production and egg quality but with the addition of $2.5 \%$, feed consumption, hen day production and feed conversion decreased. Spirulina can be used as feed supplement until $2 \%$ to give the best on production and eggs quality of Sentul chicken.

\section{ACKNOWLEDGMENT}

The author would like to thank Prof. Roostita Balia, Ph. D and Endang Sujana, S. Pt, MP., which has helped in the implementation of this study.

\section{REFERENCES}

[1] Tuti Widjastuti, Iwan Setiawan, Abun, "The Use Of Turmeric (Curcuma Domestica Val) Meal In The Rational Feed Additive On Hen-Day Production And Egg Quality Of Sentul Chicken", in Scientific Papers Series D. Animal Science, Volume Lx, 2017, 131135.

[2] Indrawati Y. Asmara, Tuti Widjastuti, Iwan Setiawan. Abun, Ruhyat Partasasmita. The Growth Performances and The Gut Health parameters of Sentul Chicken Supplemented with a various dosage of Tumeric powder. Nusantara Bioscience. ISCA Journal of Biological Science, 2018, Volume 10/No 3/pp xxx. ISSN 2087-3948/E-ISSN 2087-3956.

[3] Universitas Padjadjaran. 2018. Penelitian Academic Leadership Giants (ALG).

[4] Sulandari S, Zein Msa, Paryanti S, Sartika T, Astuti M, Widjastuti T, Sujana E, Darana S, Setiawan I, Garnida D. Local Chicken Genetic Resources. In: Diwyanto K, Prijono Sn (Eds). The Biodiversity Of Indonesia's Local Chicken Resources: Benefits And Potential, Lipi Press, Jakarta, 2007.
[5] Asmara Iy. "Risk Status Of Selected Indigenous Chicken Breeds In Java, Indonesia: Challenges And Opportunities For Conservation"Dissertation, Research Institute For The Environment And Livelihoods, Faculty Of Engineering, Health, Science And The Environment, Charles Darwin University, Darwin, Nt, Australia, 2014.

[6] Abun, Tuti Widjastuti, Kiki Haetami, Denny Rusmana, Jhondri. "Nutrient Concentrate Fermentation Based Shrimp Waste and Effect On Production Performance Phase Layer Native Chicken". Scientific Papers. Series D. Animal Science. Vol. Lx, 55 - 60, 2017.

[7] Mariey, Y. A., H. R.Samak, And M.A.Ibrahem, "Effect Of Using Spirulina Platensis Algae As Afeed Additive For Poultry Diets: 1Productive And Reproductive Performances Of Local Laying Hens". Egypt. Poult. Sci. Vol (32) (I): (201-215), 2012.

[8] Demirbas, Ayhan and Demirbas M Fatih, Algae Energy: Algae as a New Source of Biodiesel. Springer- Verlag. London, 2010.

[9] R. Buwono, and Q. Nurhasanah, Study Of Spirulina Sp Population Growth In The Different Culture Scale, 2018.

[10] Becker, E.W, Micro-Algae as A Source Of Protein. Biotechnol. Adv. 25, 207-210, 2007.

[11] Habib, M.A.B., Parvin, M., Huntington, T.C. \& Hasan, M.R. A Review on Culture, Production and Use Of Spirulina As Food For Humans And Feeds For Domestic Animals And Fish. Fao Fish. Aquacult. C., 1034, 2008.

[12] Alvarenga, R.R., Rodrigues, P.B., Cantarelli, V., Zangeronimo, M.G., Da Silva Junior, J.W., Da Silva, L.R., Dos Santos, L.M. \& Pereira, L.J., "Energy Values And Chemical Composition Of Spirulina (Spirulina Platensis) Evaluated With Broilers", Braz. J. Anim. Sci. 40, 992-996, 2011.

[13] Zahroojian, N., Moravej, H. \& Shivazad, M, "Effects Of Dietary Marine Algae (Spirulina Platensis) On Egg Quality And Production Performance Of Laying Hens". J. Agric. Sci. Technol. 15, 13531360, 2013.

[14] Spolaore, P., Joannis-Cassan, C., Duran, E. \& Isambert, A, "Commercial Applications of Microalgae". J. Biosci. Bioeng. 101, 87-96, 2006.

[15] Takashi Maoka. (2011) Carotenoids In Marine Animals. Marine Drugs Issn 1660-3397. [Online]. Available at: Http: //www. mdpi.com/Journal/Marinedrugs

[16] Kabinawa, I.N.K., Spirulina, Ganggang Penggempur Aneka Penyakit, PT Agro Media Pustaka, Jakarta, 2016.

[17] Lesson, S., and J. D. Summer., Nutrition of Chick. University Books. Guelph, Ontario, Canada, 2001.

[18] Nikodémusz, E, Páskai, P, Tóth, L.And Kozák, J., "Effect of Dietary Spirulina Supplementation on the Reproductive Performance of Farmed Pheasants", Technical Articles Poultry Industry, Pp. 1-2, 2010.

[19] Shekharam, K., L.Ventarakaraman and P. Salimath, Carbohydrate Composition and Characterization of Two Unusual Sugars from the Blue-Green Algae Spirulina Platensis. Phytochem., Vol. 26 pp. 2267 -2269, 1987.

[20] Argo, L.B. dan I. Mangisah, Kualitas FisikTelur Ayam Arab Petelur Fase I dengan Berbagai Level Azolla microphylla. Animal Agricultural Journal, 2(1), pp 445-457, 2013.

[21] Kusumasari, D., P. I. Mangisah dan I. Estiningdriati, Pengaruh Penambahan Vitamin A dan E dalam Ransum Terhadap Bobot Telur dan Mortalitas Embrio Ayam Kedu Hitam. Animal Agriculture Journal, 2(1) pp 191- 200, 2013.

[22] Brionne A, Nys Y, Hennequet-Antier C, Gautron J (2014) Hen uterine gene expression profiling during eggshell formation reveals putative proteins involved in the supply of minerals or in the shell mineralization process. BMC Genomics 15:220. 